\title{
NTQ Reports and Announcements
}

\section{Maria Shevtsova}

\section{Shakespeare in Summer}

\author{
Report on the Gyula Shakespeare Festival, 2013.
}

THIS JEWEL of a festival is now in its ninth year and, despite a twenty per cent cut to its budget because of the current economic crisis, the festival's director József Gedeon has once again made a selection of quality work that can engage different audiences. Such was the aim he set for the festival from its very inception (see NTQ 108, November 2011). Gedeon's choice included two children's shadow-plays of Romeo and Juliet and The Taming of the Shrew whose skills, narrative eloquence, and pathos I enjoyed as much as the five-to-ten-year-olds beside me. Performed by Erzébet Csortán and János Berta, these fifteenminute 'études', as they were described in the programme, were delightful introductions for future readers and spectators of Shakespeare - a reminder to theatres the world over that today's students of whatever age are tomorrow's audiences.

Unfortunately I was able to catch only the tail end of the festival and so missed most of the rest of its Hungarian offerings, among them a free jazz cum hip-hop band known as W.H., which played and sang Shakespeare's sonnets and songs; another version of the Sonnets, a spoken two-hander, this time, from the Company Ildikó Mándy was also off my radar. Other notable Hungarian events were a Taming of the Shrew, directed by Sorin Militaru from the Hungarian-speaking community of Târgu-Mures in Transylvania in Romania, together with no less than three Hamlets directed by Lázsló Boscárdi, Sándor Zsótér, and Csaba Kiss.

The latter two directors are from Budapest, where they have a strong following. Boscárdi, an ethnic Hungarian from the bilingual HungarianRomanian town of Sfântu Gheorghe, also in Transylvania, was the recipient in 2012 of the highly prestigious Director's Prize awarded by the Romanian Theatre Union (UNITER) based in Bucharest. He described his Hamlet as 'not ready yet' and, indeed, the video I managed to see of the production-to-date, although captivating, confirmed Boscárdi's own assessment. It has a boyish Ophelia (Ágnes Benedek), a street-gang-hooded, 'atmospheric', but direct Hamlet (László Mátray), and a simply presented, non-rhetorical Gertrude, Claudius, and Polonius. All seemed comfortable enough in an intriguing setting made up of a billowing plastic curtain traversed by mysterious lights and a haunting score of electronic sounds. However, the actors are clearly still looking for how to play in the various keys that Boscárdi is juggling at once, in search of balance and resolution. The layers of work that have gone into this piece are well and truly visible, and it might yet be ready for its much-awaited home showings in the autumn.

The only full-scale Hungarian production I did manage to see was Kiss's Hamlet, which was performed on the Pond Stage, built for purpose on a small lake accessed by a bridge from an adjacent park. Above the lake is the fifteenth-century Gyula castle by a Verona architect, and its flat walls and Renaissance battlements on the horizon provided a stunning backdrop for the play, giving the illusion, moreover, that its action was taking place both inside and outside the castle walls.

The serendipitously site-specific character of the production was enhanced by its natural surroundings: the lake on which Hamlet, alone in a boat, silently drifts into the dark and where, later, together with Rosencrantz and Guildenstern, he crosses the seas to England; a tall, graceful willow tree on the bank, which is lit up to play Hamlet's Father's Ghost; and just the presence of the same tree, effortlessly providing the landscape for Ophelia's death. A huge splash of water somewhere behind the willow suggests Ophelia is about to drown, but its impact is undermined, alas, when the actress reappears, unscathed and in dry clothes, to be wrapped up and buried next to Polonius in blankets on the edge of the stage.

All in all, more mileage could have been had from these lovely surroundings to gladden the hearts of romantic spectators. The aficionados in the audience were disappointed that Hamlet's harassment of his mother was left unexplored. He wears the black mourning dress she had cast aside for a bold red one whose colour signalled her 'heated' blood. Yet this hint of transvestism plays on immediate surface effect rather than probing the insights implicit in the imagery of Hamlet's transposition (regarding grief, identification, and desire, for instance - yes, even for his mother).

The festival's international productions picked up the sonnet, song, and monologue strands of its earlier part, which was Hungarian-focused for logistic reasons rather than from any wish to segregate by national category. Caroll Vanwelden, singer and pianist from Belgium, and her threeman German jazz band gave gritty, evocative renditions of sixteen sonnets to Vanwelden's music. Several were melancholy but, nevertheless, still on a harder edge than, say, Rufus Wainwright's better known sweeter, sentimental renditions used by Robert Wilson in his Berliner Ensemble production of 2009. 


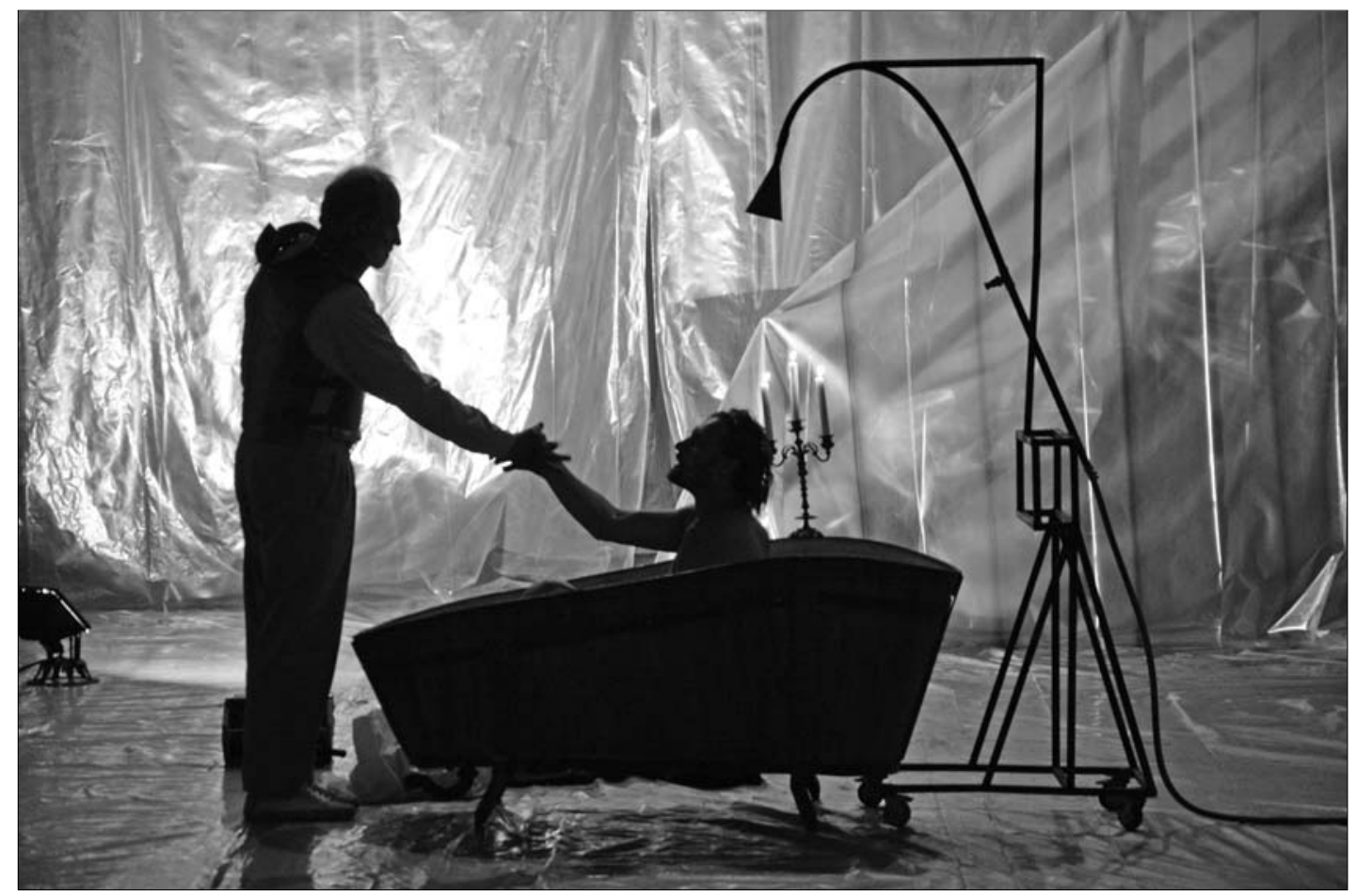

Lázsló Boscárdi's production of Hamlet at the Gyula Festival. Above: the 'intriguing setting made up of a billowing plastic curtain traversed by mysterious lights'. Below: Agnes Benedek as Ophelia. Photos: Zoltan Kiss.

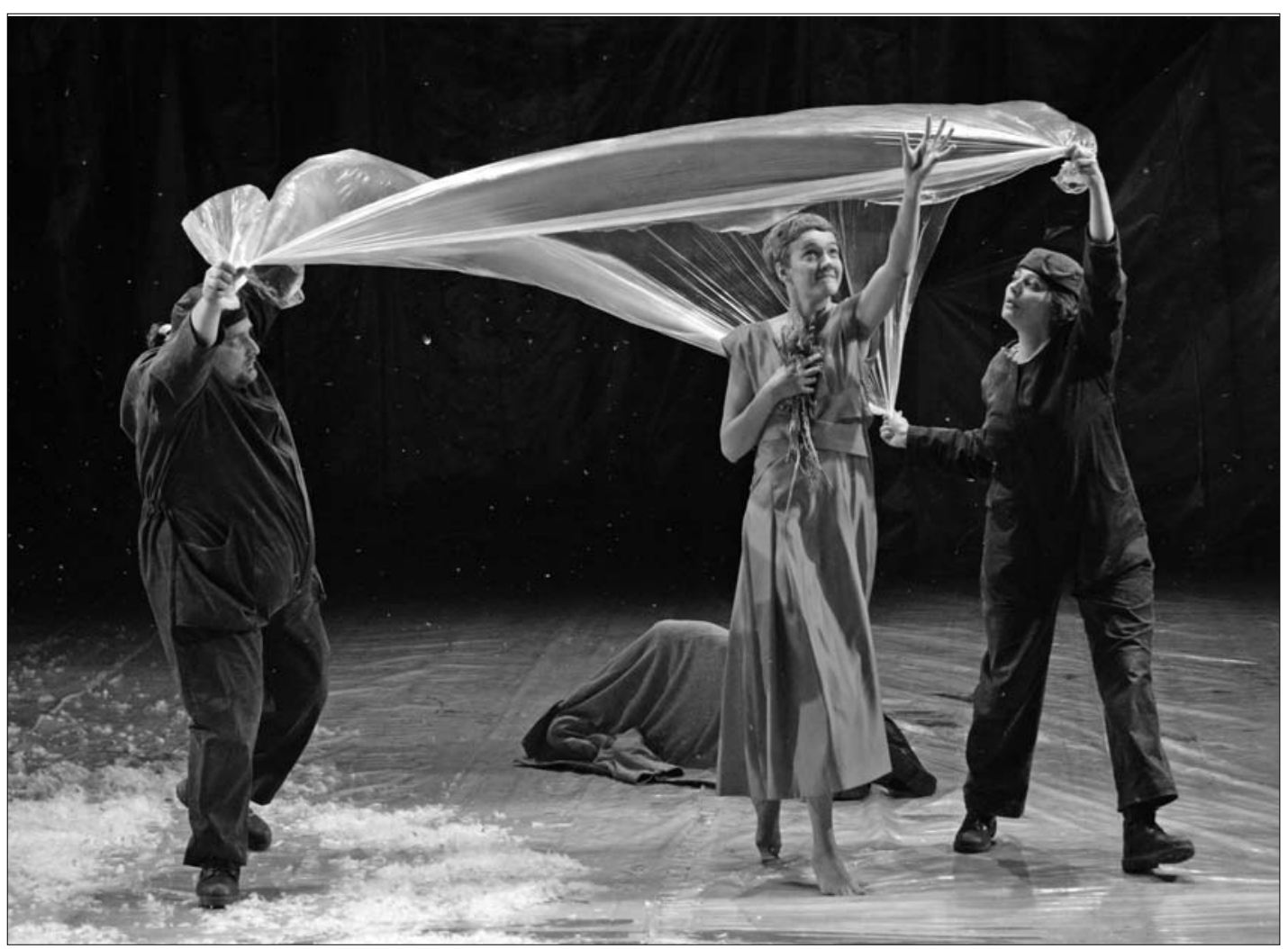




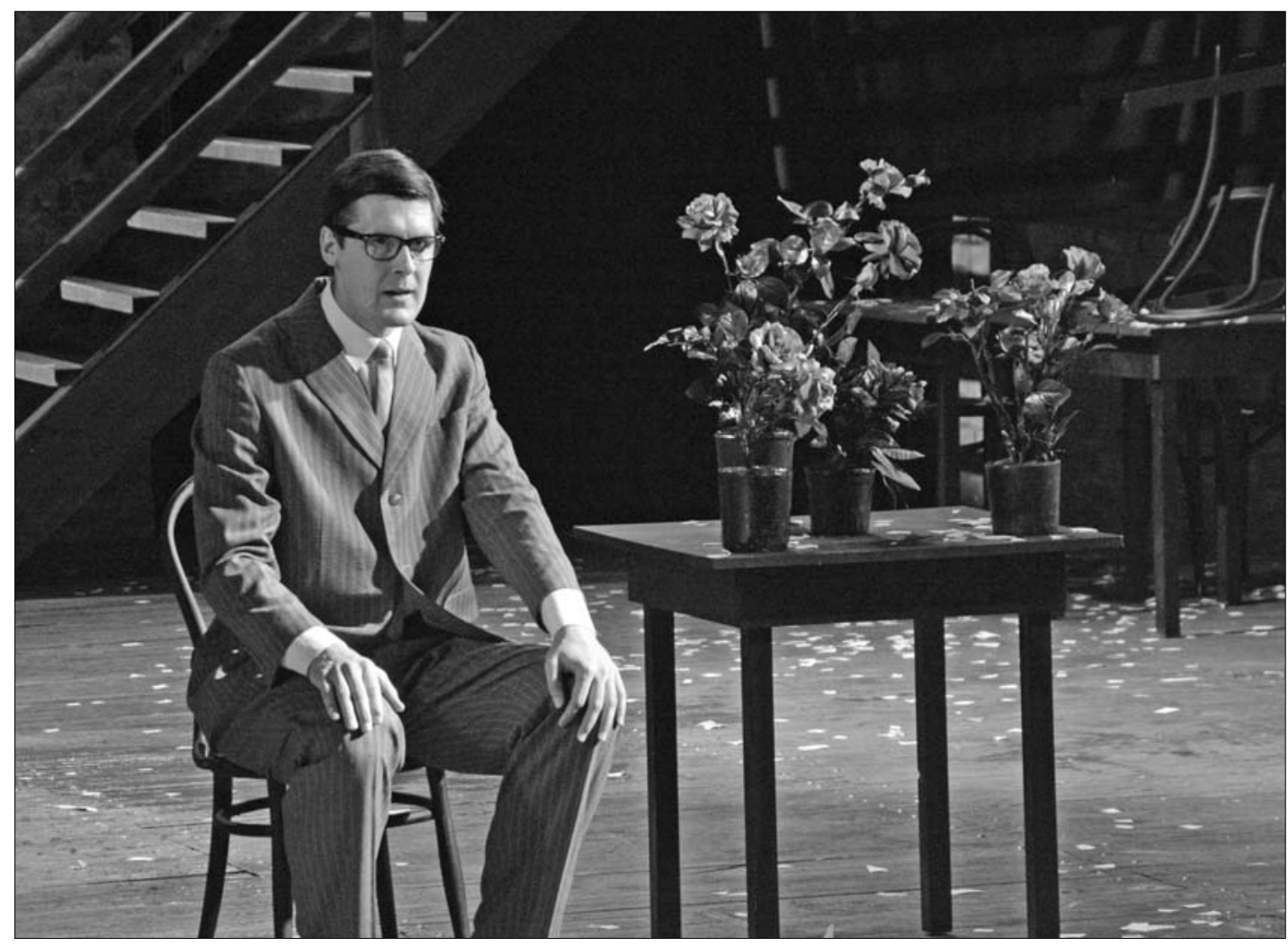

Measure for Measure directed by Yury Butusov and performed by the Vakhtangov Theatre. Above: Sergey Yepishev as Angelo. Opposite page: Yevgeniya Kreghzhde as Isabella, Photos: Zoltan Kiss.

The Wainwright-Wilson collaboration may have helped to renew the interest now evident in different countries in staging the Sonnets. Vanwelden claims she had first encountered the Sonnets further back in time and had toyed with the idea of setting them to jazz before she finally managed to do so in this past year. However, she had not planned to perform them beyond her usual jazzclub setting. The fact that they captivated audiences outdoors, in a Gyula garden, might be a litmus test for their attraction not only outside clubs, but also outside the framework of Shakespeare festivals. There can be no doubt of their effectiveness as jazz music in the hands of this ensemble, and their success in this context supports Gedeon's view that Shakespeare can be a normal, integral part of everyday culture, which is precisely what his festival promotes.

In a different, far more literary mode was Emil Boroghina's recital of Shakespeare monologues. His emphasis on sense and meaning combined with theatrical elegance and flow also showed in his choice of sonnets, taken for their philosophical and emotional links with his selected speeches. Boroghina, who is the director of the Craiova International Shakespeare Festival, founded in 1994 (See NTQ 112, November 2012), had worked as an actor before running the Craiova National Theatre. It was here that he provided the celebrated Romanian theatre director Silviu Purcarete with an international platform.

Boroghina first conceived the idea of his oneman show some thirty years ago, tweaking it to suit performances today. However, he has not changed its structure, and he has kept, as well, the connections he had made earlier between Shakespeare and several fragments he had extrapolated from the Romanian writers Mihia Eminescu and Geo Bogza. Bogza's poem 'To Be or Not to Be', which Boroghina recites near the beginning, is worth quoting here in full to indicate the tone and tenor of his performance. His recital, although large in scope, is presented intimately - an actor's modest homage to the deep seriousness of Shakespeare's work. The poem, in translation from the Romanian by Iolanda Manescu, goes:

On this Earth - that from afar is shaped like an orange - once lived a man, an English man named William Shakespeare. For four hundred years, men and women hailing from the most different lands, speak, at momentous occasions, the words through which he set in motion, like the waves of the 
sea among rocky shores, the whole tumult of the human destinies: to be or not to be?

The great themes of Hamlet's soliloquy run in an undercurrent through Boroghina's compilation, but so do those of 'All the world's a stage' from As You Like It. Echoes call upon echoes, from King Lear's 'When we are born, we cry that we are come / To this great stage of fools' to Sonnet 110, 'Alas 'tis true, I have gone here and there / And made myself a motley to the view'. Cross-references and resonances go back and forth, covering a wide range of Shakespeare works, including most of the history plays.

The contrast between Boroghina's presentation and Steven Berkoff's Shakespeare's Villains, which followed a day later, could not have been sharper, largely because Berkoff used his considerable talents to turn anything remotely familiar into laughter. Thus Hamlet's 'To be or not to be' was parodied with a wink at Laurence Olivier and, having defined Hamlet as a 'serial killer', Berkoff proceeded to provide the textual evidence for his case. Gertrude appeared in his gallery of villains, as did Juliet and Lady Macbeth - all three as drag queens - and served as pretexts for mock morals to various funny stories. Male villains featured the obvious Richard III and the less obvious Lear. The whole was interspersed with asides, some making an educational point or two, while others were pretty well inconsequential, like the patter of a seasoned stand-up comic. It could just as easily have gone into a classroom or a pub as form part of a summer celebration.

Songs of Lear performed by Wroclaw's Song of the Goat was a counterpoint to Berkoff's populist fling. The show had had its international premiere at the 2012 Edinburgh Festival, from which it returned to Poland with three prestigious Fringeevent awards, accompanied by accolades from critics and public alike. It was essentially a concert whose women singers were fitted out in the proverbial 'little black dress' - short enough to show leg, but not short enough to be vulgar while its men looked more casual in open-necked black shirts and trousers. Grouped in a semicircle, they poured out songs with an extraordinary energy typical of Goat performers, accentuating rhythms and cadences for dramatic shading: the music was, in fact, the drama. Occasionally, they formed smaller male or female groupings to preserve a particular vocal colour. Or else they came together in twos - the case especially of Anna Zubrzycki and Monika Dryl, who sang forceful duets sitting on chairs they had brought forward into centre space.

Grzegorz Bral, co-founder with Zubrzyski of Song of the Goat, sometimes acted as a Kantorlike director/conductor within the performance, or as a narrator connecting songs to this or that bit of plot in King Lear. But his notes were not necessary. The polyphonic songs by Jean-Claude Acquaviva (from the Corsican group A Filetta) and by Maciej Rychly (commissioned for the

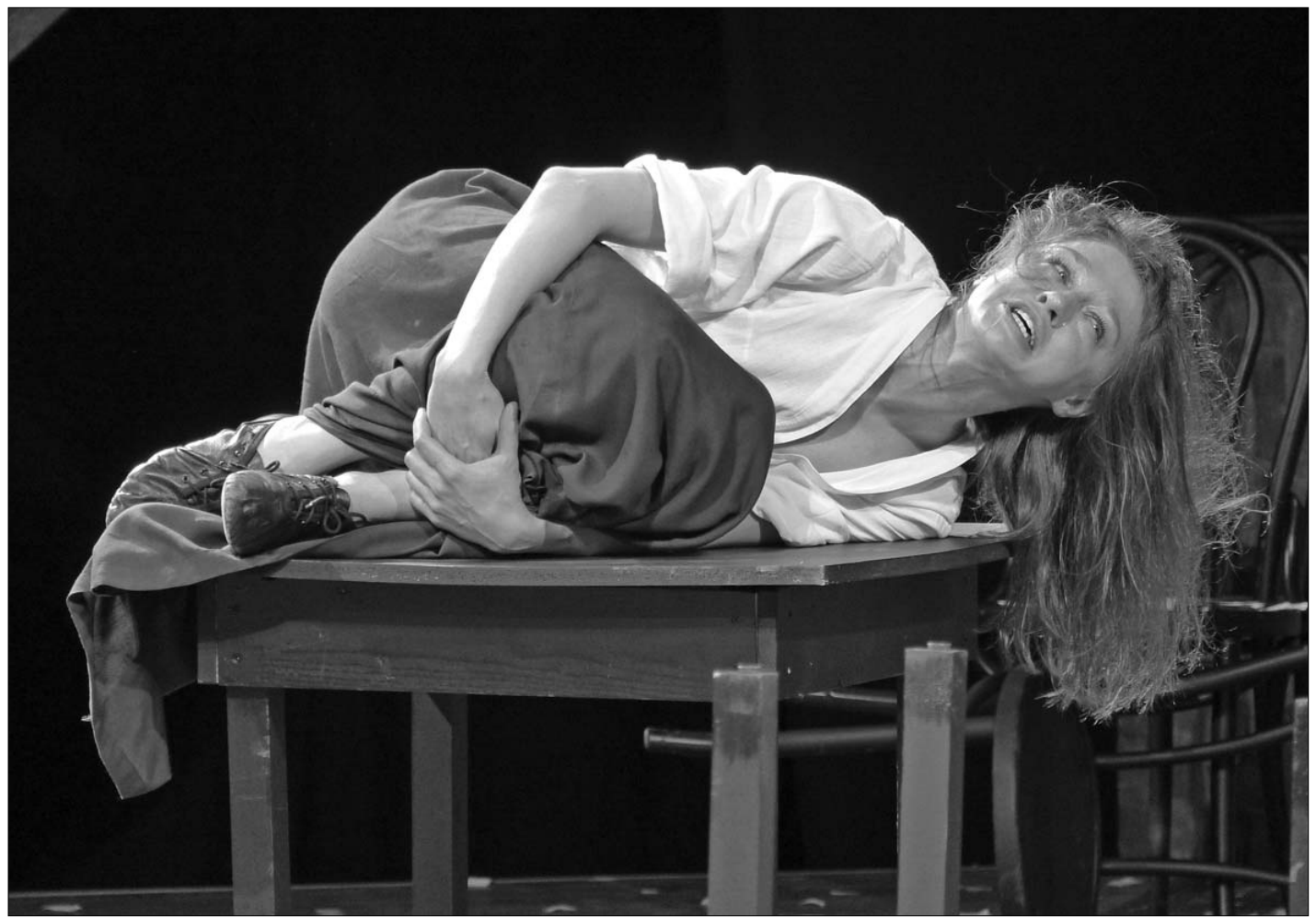


production) were beautiful, self-contained pieces whose content, although little to do with King Lear, had considerable metaphorical significance. Annotation was of least use for a song performed with tremendous emotional force by Zubrzycki, which irresistibly conjured up a mother's lament for the dead of war. It was a theatrical masterpiece: the chorus beat on chairs turned upside down to become the drums of war while voices soared; Zubrzycki shot out her arms in a Meyerholdian 'biomechanical' way - a machine of war inspiring dread, even as she mourned its fallen. The scene was more than capable of doing its own visceral work.

The most powerful piece of the festival's international section was Measure for Measure directed by Yury Butusov and performed by Moscow's Vakhtangov Theatre. It was not difficult to see why the production had been such a great success at the World Shakespeare Festival, which formed part of the cultural events for the Olympic Games in London in 2012. The Vakhtangov's strong ensemble acting was crowned by the performance of Evgeniya Kreghzhde, whose Isabella vibrated with fluctuating emotions of such sincerity that, when she wraps her arms spontaneously around Angelo to beg for her brother's life, the audience gasps at the sheer purity of it. This is an Isabella who could not begin for one second to imagine what cunning or wiles might be.

Nor does Sergey Yepishev, in the role of Angelo, for one instant cast Isabella's sincerity in doubt. He shows Angelo desperately wanting to embrace her, his fingers near her back twitching to touch it, but not daring to lay a finger on it. At the same time, Yepishev shows just how, and at which precise moment, Angelo's desire awakens with the fury that, henceforth, he must struggle to control. The scene contains in a nutshell the astonishing riddles concerning sex, love, uncompromising faith, genuine good, and misguided power posed by Shakespeare's play. Butusov unpicks them with his agile imagination not only when Isabella's innocent rapture ignites Angelo, but also in a subsequent scene when Angelo's fire turns ugly, and, in a series of speedy tacks and moves, heads off and blocks Isabella's attempts to flee along the sides of a long rectangular table that Yepishev and Kreghzhde had suddenly thrown together out of the small tables scattered across the space. What starts out looking like a stagemanagement job turns almost at once into a scene of attempted rape. The tables sent flying are part of that attempt, and it is terrifying.

The production's unexpected dénouement is no less of a shock. Butusov, with great directorial insight, has Yepishev play both Angelo and the Duke; and this doubling makes the Duke and Angelo two sides of the same coin. The problem, of course, is how to deal with the scene when they meet, and Butusov solves it in the easiest way, which is to cut it out altogether. The solution might be simple, but its consequences are potent, since the tension generated through the AngeloIsabella confrontation continues without respite into the meeting between the Duke and Isabella. So, by always being the Duke's double, Angelo can turn instantaneously into the Duke for dramatic reasons.

The Duke declares his love to Isabella and asks her to marry him. What happens next is a bolt from the blue. Isabella slaps the Duke hard on the face, and her slap shows that she interprets his intimacy as a proposition rather than an honest avowal of love. And she is not wrong. What follows is a re-run of the earlier attempted rape. Now it is even more aggressive and the Duke, unlike Angelo, succeeds in pinning Isabella down. Kreghzhde's contorted face and body are the rape. Butusov, it is clear, envisages the world of men of power as a world of predators. This perception comes as a surprise not only because the role and the actions are mirrored, and the rerun is more horrifying than the 'original'. Nor is it only because spectators expect Shakespeare's 'happy' ending. It is unexpected primarily because Butusov comes right up, face to face, with women's fears, grasps the point in one go, and is outraged strongly enough to speak not for, but with women.

There is much else to note in this remarkable production, including how rubbish is poured out on to the stage at the beginning and swept away by a team of men with huge brooms. This unspoken prologue is emblematic of Angelo, the new broom for public order. Rubbish is subsequently strewn all over the stage at the end, and is swept up again by the same industrial-size brooms. The performance thus comes full circle, and the rubbish-tip stage of the opening scene makes complete sense: the Duke's realm never was squeaky clean, and never will be.

Several Wilson-like movements and poses, with touches of what Vakhtangov, emulating Meyerhold, called the 'grotesque', suggest that stylization can work hand in glove with psychological theatre, as, indeed, Vakhtangov believed it could and should. Not everything gelled in Butusov's direction, but he is a director to be reckoned with. Gedeon's decision to invite Measure for Measure to the Gyula Shakespeare Festival, regardless of its impact on his decreased budget for increased running costs, demonstrates how deeply he believes that the quality of artistic work justifies the expense. Such quality, he is convinced, protects the theatre not only in times of economic and political strife, but from the corrosion of commercial and utilitarian values. True, there is a moral to this story. 